\title{
The effect of educational intervention on the practice of menstrual hygiene among rural adolescent students in El-Mehala EI- Kobra villages in Gharbia governorate \\ Ikbal F. El-shafie \\ Professor of Community Health Nursing, \\ Faculty of Nursing, Tanta University \\ Amaal M. El-Zeftawy \\ Lecturer of Community Health Nursing, \\ Faculty of Nursing, Tanta University
}

Abstract

Adolescence is the most important and sensitive period of one's life. Menstruation and menstrual practices are still clouded by taboos and socio-cultural restrictions resulting in adolescent girls remaining ignorant of the scientific facts and hygienic health practices, which sometimes result in adverse health outcomes. So learning about menstrual hygiene is a vital aspect of health education for adolescent girls. The aim of the study was to evaluate the effect of educational intervention on the practice of menstrual hygiene among rural adolescent students in El-Mehala El- Kobra villages in Gharbia governorate. A quasi- experimental study was used. The study was conducted in five villages with preparatory schools selected by purposive random sample technique. The preparatory schools in each village were included in the study. The study sample comprised one class of third grade in each preparatory school in the previous setting. The total number of girl students was 183. Two tools were developed to obtain the necessary data:- Tool (I) A questionnaire sheet, and tool (II) Assessment of facilities for menstrual hygiene at schools and homes. The age of the study sample ranged from 13-16 years, with a mean of $14.55 \pm 0.55$ years. More than half of them $(53 \%)$ their duration of menstruation ranged from 3-5 days and more than half of them $(54.1 \%)$ their family size were 5-6 members. Mothers were the most $(90.1 \%)$ common preferred sources of information about menstruation and menstrual hygiene. Regarding menstrual hygiene practices (54\%) weren't bathing during menstrual period, all of the girls reported that they used pads during menstruation period, more than half of them changed pads twice daily and (56.8) of them kept pads in special places. There were significant improvement in the score of knowledge and practices among study sample regarding menstrual hygiene pre, immediate and 3 months post-program ( $\mathrm{f}=.194 .26^{*}, \mathrm{p}=0.0001^{*}$ and $\mathrm{f}=162.14^{*}, \mathrm{p}=0.0001^{*}$ respectively). It can conclude from this study that the health education program was effective and have positive effects on the menstrual knowledge and practice of rural adolescent students. Mothers were the most important source of information about menstruation and menstrual hygiene of rural adolescent students. The study recommended that implementing educational program among elementary, preparatory, and secondary schools about menstrual hygiene for improving students' menstrual knowledge and to encourage safe and hygienic practices among the adolescent girls and bring them out of traditional beliefs, misconceptions and restrictions regarding menstruation. Also it is important that nurses participate in public health awareness program to create better awareness among adolescents. Such initiative would make adolescents population self sufficient to manage their health and wellbeing.

Key words: Menstrual education program (MEP), menstrual knowledge, practices, menstrual hygiene, menarche, adolescents. 


\section{Tanta Scientific Nursing Journal}

\section{Introduction}

Early adolescence is a time of physical, intellectual, emotional, and social development during which young people confront many questions. Physical maturation and particularly sexual maturation, has significant effects on selfconcept and social relationships during this period ${ }^{(1)}$.Adolescence is the period of transition from childhood to adulthood. WHO has defined adolescence as the age group of 10-19 years This transitional period is marked with the onset of menarche ${ }^{(2,3)}$.

Adolescents comprise $20 \%$ of the world's total population ${ }^{(4)}$. Out of 1.2 billion adolescents worldwide, about $85 \%$ live in developing countries ${ }^{(5)}$.Adolescents in Egypt form around 25 percent of the country's population, and represent even greater proportion of the country's human potential $^{(6,7)}$.

Menarche is the onset of menstruation and it is one of the most significant milestones in a woman's life. The mean age at menarche varies from population to population and is known to be a sensitive indicator of various characteristics of the population including nutritional status, geographical location, environmental conditions, socioeconomic standard and indulgence in strenuous physical activity ${ }^{(1,3,8,9)}$. Studies suggested that menarche tends to appear earlier in life as the sanitary, nutritional and economic conditions of a society improve ${ }^{(10,11) .}$ For most females, it occurs between the age of 10 and 16 years until 45 to 55 years; however, it shows a remarkable range of variation ${ }^{(9)}$. The normal range for ovulatory cycles is between 21 and 35 days. While most periods last from three to five days, duration of menstrual flow normally ranges from two to seven days. For the first few years after menarche, irregular and longer cycles are common. A woman will have approximately 500 periods in her lifetime. The estimated blood loss is between $50 \mathrm{ml}$ and $200 \mathrm{ml}^{(9,12,13)}$.

Further evidence for menstruation as a taboo topic is the ways in which menstruation is discussed and the language used to describe it reveal how society views the events. Across cultures, girls frequently take about the physical and psychological implications of their menstrual cycles. Egyptian culture like other cultures, women and girls use different slang's terms when they refers to menstruation. Also girls are considered menstruation is an embarrassing, odorous, painful, shameful and hygienic problem that girls must cover up and hide from public view, particularly men's view ${ }^{(14,15)}$. So before bringing any change in menstrual practices girls should be educated about the facts of menstruation and its physiological implications. The girls should be educated about the significance of menstruation and development of secondary sexual 


\section{Tanta Scientific Nursing Journal}

characteristics, selection of a sanitary menstrual absorbent and its proper disposal. There is a need for compulsory sex education and health education on menstrual hygiene so that they can discuss freely about it without hesitation ${ }^{(1,16)}$.

Hygiene related practices of young girls during menstruation are of considerable importance as they don't have experience, especially during the onset, as menstrual flow could occur accidentally while they are still in class or out of home. Availability of water and privacy in schools to change products and dispose used materials has got psychological impact and disruption of academic performance ${ }^{(1)}$. The manner in which a girl learns about menstruation and its associated changes may have an impact on her response to the event of menarche. Although menstruation is a natural process, it is linked with several misconceptions and practices, which sometimes result into adverse health outcomes ${ }^{(17)}$. Because of various myths, misconceptions and restrictions practiced during menstruation, the adolescent girls often develop negative attitudes towards this natural physiological phenomenon. The majority of the girls lack scientific knowledge about menstruation and puberty. Adolescent girls often are reluctant to discuss this topic with their parents and often hesitate to seek help regarding their menstrual problems. Unhygienic menstrual practices may affect their health such as increased vulnerability to Reproductive
Tract Infections (RTIs) and Pelvic Inflammatory Diseases (PIDs) and other complications. Use of sanitary pads may be increasing but not among girls from rural and poor families ${ }^{(17,18,19)}$.

Girls should be educated about "menstruation and healthy menstrual practices" through expanded programmes of health education in schools. Data on their level of knowledge and practices are beneficial for planning programmes for improving their awareness level ${ }^{(16)}$.Hence; this study was done to evaluate the effect of educational intervention on the management of menstrual hygiene among rural adolescent students.

\section{Aim of the study}

The aim of the study was to evaluate the effect of educational intervention on the practice of menstrual hygiene among rural adolescent students in El-Mehala El- Kobra villages in Gharbia governorate .

\section{Materials and Method}

\section{Materials}

\section{Study design:-}

A quasi- experimental study was conducted to evaluate the effect of health education intervention on the practice of menstrual hygiene among rural adolescent students in El-Mehala El- Kobra villages in Gharbia governorate .

\section{Setting:}

El-Mahala El- Kobra center at El-Gharbia governorate has 55 villages. The study was conducted at five villages of them that had 


\section{Tanta Scientific Nursing Journal}

preparatory schools. They were selected by purposive random sample technique. The preparatory schools in each village were included in the study. Their number was five. These villages were El-Amria, Saft trab, El-gabria , El-hayatem and Mehalt Abo- Ali village.

\section{Sample:-}

The study sample comprised one class of third grade in each preparatory school in the previous setting. The students' number in each class ranged from 24 to 46 students girls. The total number of all participants was 183girl students.

\section{Tools of the study:-}

Two tools were developed by the researchers to obtain the necessary data:-

Tool (I) A questionnaire sheet.

This was developed by the researchers to collect data about the study sample. This tool included the following parts:-

Part(1) Socio-demographic characteristics :This included name, age, grade level, religion, with whom she lives at present, number of family members, level of parent's education, parents' occupation, economic status of the family, number of rooms, and source of drinking water .

\section{$\underline{\operatorname{Part}(2) \quad \text { knowledge regarding }}$ menstruation and menstrual hygiene:-}

This included the following:-

1. Age of menarche, place of the first menstruation occurred, first reaction experienced for the first time, and protective material used during the first days at menarche.

2. Communication with her mother about menstruation, background about menstruation before starting menstruation, source of information about menstruation before she started.

3. Meaning of menstruation, causes of menstruation, place of blood flow of menstruation come from, normal age for menstruation to begin, the average normal menstrual cycle interval, the average of her menstruation flow, ability of girl to go to school during the menstruation, ability to cook food during the menstruation, and alternative names for menstruation,.

4. Restrictions practiced by family or community during menstruation such as prohibit attendance of any religious occasion, eating certain foods, playing, household work, attendance of school attendance any marriage ceremony during menstrual period.

5. Preferred source to receive more information on menstrual matter, and sources of information about menstruation and menstrual hygiene.

\section{Part (3) Previous menstrual health problems:-}

This included adolescent girls 'experience of any health problems during menstruation, and severity of each problem and their act regarding these problems and the effect of these problems in school performance. 


\section{Tanta Scientific Nursing Journal}

Part (4) Practices related to current menstrual hygiene:-

This included bathing during menstruation, eating food on menstruation, pads uses during menstruation( types, frequency of change, number of pads during menstruation, methods of disposes the pads, reusing the pads), alternative name for the menstrual protective materials at home with family members or friends, cleaning of genitalia for menstrual purpose and materials use in this cleaning area and maintenance of privacy, activity and rest during menstruation, sources of information regarding these practices.

Tool (II) Assessment of facilities for menstrual hygiene.

This tool included the following parts:-

Part (1) Assessment of facilities for menstrual hygiene at the home:-

This included availability of special room, water supply, number of latrines, method of waste disposal, availability of cleansing materials and availability of money to pay pads.

Part (2) Assessment of facilities for menstrual hygiene at school:-

This assessed by using checklist for observation of schools. A checklist was developed and used by the researchers to make an inventory on sanitary facilities available in the schools. The list contained questions on availability and accessibility of water near and in latrines, privacy and adequacy of latrines, availability of disposal sites for menstrual hygiene material, and the presence of clinic or clinic services to the students for consultation and counseling during menstruation within the school premises.

Method

1- Before conducting the study, a written permission letter was obtained from the Faculty of Nursing Tanta University to responsible authorities of Ministry of Education and school principals.

2- Ethical considerations: -

a- Students' informed consent was obtained.

b- Rights, anonymity and confidentiality of the respondents were respected in all phases of the study.

d- All students were informed about the purpose and the benefits from this study.

3- Before embarking on actual study, a pilot study was carried out on twenty students chosen from one school of the schools included in the study. Those students were excluded from the study sample. In order to test the reliability of the tool, test - retest was done . The pilot study conducted twice, 2 weeks apart. The first test done and analyzed, its results were $78.74 \%$ and the second retest was $78.13 \%$.

4- The tool was revised submitted to seven experts in community health nursing from faculty of nursing two professors 


\section{Tanta Scientific Nursing Journal}

and three lectures and public health and preventive medicine from faculty of medicine two professors Tanta University.

5- Opinion of experts on tools of the study was analyzed face validity $95 \%$ content validity $97 \%$.

Data collection: -

-Tool (I) and tool (II) part (1) administered individually to each student of the study sample before start program.

-Tool (I) part (2, and 4) administered individually to students participate in the program three times before, immediate and after three months of implementation of the program.

- Tool (II) part (2) administered by the researcher one time only for each school at the beginning of the study.

7- Implementation phase of the program. The first step of developing educational intervention program was formulating program objectives. The general aim of the program was to evaluate the effect of educational intervention on the management of menstrual hygiene among rural adolescents' students. The field work of this study was done in five months starting from the November 2010 to the march 2011. Each class of girl students was first informed about the program objectives to attain their active participation and cooperation during the implementation of the program.
The researchers visited each school several times:-

- First time to meet the director of each school, introduce the official letter, explain the objectives of the program and determine the time of the next visit to start the program implementation.

- Second time for explanation of the purpose of the study and performing the pretest (45 minutes).

- Third and fourth times for implementing educational intervention regarding menstruation and healthy menstrual practices. The contents of the program were included the following items short note about anatomy of female genital tract, meaning of menstruation, causes of menstruation, place of blood flow of menstruation come from, normal age for menstruation to begin, the average normal menstrual cycle interval, the average of her menstruation flow, ability of girl to go to school during the menstruation, ability to cook food during the menstruation, and alternative names for menstruation

- Also the contents of the program were included restrictions practiced by family or community during menstruation such as prohibit attendance of any religious occasion, eating certain foods, playing, household work, attendance of school attendance any marriage ceremony during menstrual period. The personal 


\section{Tanta Scientific Nursing Journal}

hygiene and practices during menstruation were taken more attention during the program.

- The contents of the program were organized and presented in two sessions each session was (90 minutes). This was imparted to the rural adolescents school girls through lecture, group discussion with the help of audio-visual aids (power point program) .Each session was followed by question-answer session to clarify their doubts and answer their questions related to menstruation and menstrual hygiene practices.( 45 minutes).These sessions were done in computer laboratory in each school. Then the questionnaire was again administered to the students (immediate post test).

- The last time after three months from the implementation of the program to dopost test to asses the effect of educational intervention and the remaining knowledge and practices about menstruation and menstrual hygiene practices.

6- Evaluation of the program.

Three assessments were done to the girl students in order to test their knowledge, practices about menstruation and menstrual hygiene. Therefore, tool (I) parts (2and 4) were used three times before, immediate and after implementation of the program.

\section{Statistical analysis}

The data were computerized and verified using the SPSS ( Statistical package for social science) version 13 to perform tabulation qualitative variables were described in frequency and percentages, while quantitative variables were described by means and standard deviation. Analysis of collected data was done through the use of several statistical tests as: Chi-square $\left(\mathrm{X}^{2}\right)$. $\quad \mathrm{P}$ values of $<0.05$ were considered statistically significant.

\section{Results}

Table (1) represents the distribution of the studied sample according to their menstrual history and socio-demographic characteristics. It shows that the age of the studied sample ranged from 13-16 years with a mean of $14.55 \pm 0.55$ years with a median of 15 years. Nearly two thirds of them $(62.8 \%)$ were aged 9-11 years at menarche, more than half of studied sample (53 \% and $56.8 \%$ respectively) their duration of menstrual flow ranged from 3-5 days and average of their menstrual interval ranged from 26-30 day. The majority of the studied sample (95\%) were living with their parents, and more than half of them their family size ranged from 5-6 members .Regarding educational level of their parents , more than half of fathers and mothers (53.6\% and 60.1 respectively ) were illiterates and basic educational level. The majority of them their mothers' occupation was house wife. Nearly two thirds of the 


\section{Tanta Scientific Nursing Journal}

studied sample $(60.7 \%$ and $61 \%$ respectively) their family income were enough and their source of drinking water was public resources and the majority of them (73.8\%) their living rooms ranged from 3-5 room.

Table (2) shows that distribution of the studied sample according to their reaction , physical symptoms at menarche and their sources of information about menstruation the table shows that the majority of the studied subjects $(94.6 \%)$ had menarche at home and the reaction to menarche was $(70.5 \%)$ of them run to their mothers, $6 \%$ were embarrassed and $5.5 \%$ were cried. The majority of them (80.3\%) had abdominal and back pain as physical symptoms at menarche, more than two thirds (68.3\%) reported that menstruation is a special event of girl .regarding the awareness about menstruation before encompassing menarche it is evident that nearly half of the studied sample were awarded and the most important previous and preferred source of information about menstruation was mothers $(60.2 \%$ and $90.1 \%)$ respectively.

Table (3) elicits distribution of the studied sample according to their usage of pads during menstruation, advantages and disadvantages of pads. The majority of studied sample $(83.1 \%$ and $73.7 \%$ respectively ) reported that they prepared commercial pads as protective materials for menarche and buy it by them self. The table shows that all studied sample used pads during menstruation and the majority of them (80.9\%) used commercial pads, only (9.8\% and 6\% respectively) used knew clothes and old clothes. Regarding change pads at school only (19.7\%) of studied sample changed pads at school, more than half of them (51.9\%) reported good absorbent as advantages of using pads and nearly two thirds of them (63.4 and 61.2\%) reported that there was not disadvantages of using pads and their mothers were the main source of information about practices regarding menstruation.

Table (4) represents distribution of the studied sample according to their health problems during menstruation. The table shows that the majority of studied sample $(83.1 \%)$ had health problems during menstruation and nearly half of them (47.5\%) had abdominal and back pain and $(9.3 \%)$ of them had irregularity of menstruation. Regarding severity of pain nearly half of them $(48.6 \%)$ reported that pain was interfering with school activities and more than one third of them (36.6\%) used traditional medicine as an intervention for relieving health problems. The majority of the studied sample(78.7\%) was felt with discomfort in school during menstruation and nearly half of them (48.6\%) reported that health problems affect their school achievement. 


\section{Tanta Scientific Nursing Journal}

Table (5) represents distribution of the studied sample according to their specific knowledge regarding menstruation. The table shows that before the implementation of the program $(15.8 \%, 12 \%$ and $28.4 \%$ respectively ) reported that the age of 9-16 years as age of menarche, 3-7 days as average of menstrual flow and 20-35 days as average of menstrual interval in normal girls, significant improvement was observed regarding these items from preprogram, immediate post-program and 3 months postprogram. In the preprogram it was observed that nearly one thirds of the studied sample reported that menstruation is a physiological process, nearly one quarter of them (20.2\%) reported that hormonal activity as a cause of menstruation and more than one third of them $(38.8 \%)$ did not know origin of menstrual bleeding. these answers were changed immediate post-program and 3 months post-program to be $(97.3 \%, 98.5 \%$ and $97.3 \%$ and $98.5 \%$ and $97.3 \%)$ respectively.

Table (6) regarding knowledge of studied sample regarding types of restrictions practiced during menstruation. In the preprogram more than half $(56.8 \%)$ of them did not attend school, more than one quarter of them did not attend marriage ceremony, about three quarter of them $(75.4 \%)$ did not eat all types of food such as vegetables( onion, cabbage and cauliflower), the majority of studied sample (85.2\%) did not perform household work during menstruation. After implementation of heath educational intervention program there were significant improvements among these items.

Table (7) represents distribution of the studied sample according to their specific practices regarding menstrual hygiene. It shows that in the pre test phase more than half of the studied sample ( $54.1 \%$ ) did not bath during menstruation. while in the post test phase the most of them $(98.5 \%$ and 95.6\% respectively) bathed during menstruation and $(97.3 \%)$ of them bathed daily. In the preprogram all of the studied sample (100\%) used pads during menstruation and majority of them (80.9\%) used commercial pads and about half of them (50.8) changed pads twice daily. Regarding the method of disposal of the pads nearly half of them (45.9\%) disposed the pads in house dustbins. In the immediate post-program and 3 months postprogram the majority of them $(98.5 \%$ and 96.7\%) respectively used commercial pads and changed it when needed and $(98.5 \%$ and 97.3\%) properly disposed the pads, i.e. they wrap the used pads in paper bag and disposed in the place used for solid waste disposal ( house dustbin). Regarding cleanliness of external genital area, keeping privacy during doing hygiene, daily living activity and rest during menstruation. There were significant improvements from pre program, immediate post-program and 3 


\section{Tanta Scientific Nursing Journal}

months post-program $X^{2}\left(16.25^{*}, 26.25^{*}\right.$, $36.28^{*}$ and $10.25^{*}$ ) respectively $\mathrm{P}<0.5$.

Table (8) represents distribution of the studied sample according to presence of facilities for hygienic care during menstruation at home. It shows that more than half studied sample (57.4\%) had special room. the majority of them $(88.0,84.2$ and $95.8 \%$ )respectively had water and waste disposal, enough money for buying pads and enough cleansing materials (soap, antiseptic solution and shampoo).

Table (9) represents distribution of the study group according to presence of facilities for hygienic care during menstruation at school .it shows that all schools were governmental schools. Sixty percentages of schools had more than 700 students. Regarding number of toilets, latrines designated for girls, tap water, availability of tap water near and in the latrines, clinic in the school and social workers it was found that all schools had them. Three schools did not have a pit for waste disposal and two of them did not have place for burning waste disposal. The daily schedule for cleanliness of latrines was twice daily for majority of schools (80\%).

Table (10) represents score of knowledge among studied sample regarding menstrual hygiene Pre, Immediate and 3 Months PostProgram. The table shows that in the preprogram only $(9.3 \%)$ of studied sample had good score of knowledge but the majority of them $(89.1 \%$ and $85.2 \%$ respectively) had the same score immediate post-program and 3 months post-program. It shows also there were significant improvements between score of knowledge from pre program, immediate post-program and 3 months post-program $\mathrm{F}=194.26^{*}$ and $\mathrm{P}<0.5$.

Table (11) represents score of practices among studied sample regarding menstrual hygiene Pre, Immediate and 3 Months PostProgram. The table shows that in the pre program only $7.1 \%$ of studied sample had good score of practices this score was improved immediately post program and three months post program to be $(85.2 \%$ and $79.8 \%$ respectively. It shows also there were significant improvements between score of practices from pre program, immediate post-program and 3 months postprogram $\mathrm{F}=162.14 *$ and $\mathrm{P}<0.5$.

Table (12) and figure (1) represent relationship between knowledge and practices of the studied students regarding menstrual hygiene pre, post and 3 months post-Program. There was significant relationship between students' knowledge and practice regarding menstrual hygiene pre, post and 3 months post-program $\mathrm{P}<$ 0.5 . 
Tanta Scientific Nursing Journal

Table (1) Distribution of the studied sample according to their menstrual history and sociodemographic characteristics.

\begin{tabular}{|c|c|c|}
\hline \multirow{2}{*}{$\begin{array}{l}\text { Socio-demographic } \\
\text { Characteristic }\end{array}$} & \multicolumn{2}{|c|}{$\begin{array}{c}\text { Study Group } \\
183 \\
\end{array}$} \\
\hline & No & $\%$ \\
\hline Age & & \\
\hline 13 & 2 & 1.1 \\
\hline 14 & 81 & 44.3 \\
\hline 15 & 97 & 53.0 \\
\hline 16 & 3 & 1.6 \\
\hline Range & \multicolumn{2}{|l|}{$13-16$} \\
\hline Mean \pm SD & \multicolumn{2}{|l|}{$14.55 \pm 0.55$} \\
\hline Median & \multicolumn{2}{|l|}{15.00} \\
\hline Age of study group at menarche & \multirow[b]{2}{*}{115} & \multirow[b]{2}{*}{62.8} \\
\hline $9-11$ & & \\
\hline $12-14$ & 50 & 27.4 \\
\hline $15+$ & 18 & 9.8 \\
\hline Duration of menstrual flow of study group & \multirow[b]{2}{*}{97} & \multirow[b]{2}{*}{53.0} \\
\hline $3-5$ & & \\
\hline $3-7$ & 42 & 23.0 \\
\hline $5-7$ & 44 & 24.0 \\
\hline Average of menstrual interval of study group & \multirow[b]{2}{*}{52} & \multirow[b]{2}{*}{28.4} \\
\hline $20-35$ & & \\
\hline $26-30$ & 104 & 56.8 \\
\hline $30-35$ & 27 & 26.8 \\
\hline Living with & \multirow[b]{2}{*}{174} & \multirow[b]{2}{*}{95} \\
\hline Parents & & \\
\hline Father only & 3 & 1.6 \\
\hline Mother only & 6 & $3 . .3$ \\
\hline \multicolumn{3}{|l|}{ Family size } \\
\hline $3-4$ & 45 & 24.6 \\
\hline $5-6$ & 99 & 54.1 \\
\hline $7+$ & 39 & 21.3 \\
\hline
\end{tabular}

Vol. 2 No. 2 May 2012 


\section{Tanta Scientific Nursing Journal}

\begin{tabular}{|l|c||c||}
\hline Educational level of fathers & & \\
Illiterate Primary education & 17 & 9.3 \\
Basic education & 81 & 44.3 \\
secondary education & 54 & 29.5 \\
University education & 31 & 16.9 \\
Other & & \\
\hline \hline Educational level of mothers & & \\
Illiterate & 47 & 25.7 \\
Basic education & 63 & 34.4 \\
Secondary school & 53 & 28.9 \\
University education & 20 & 10.9 \\
\hline Fathers' occupation & 167 & 91.3 \\
Work & 16 & 26.2 \\
Not work & & 73.8 \\
\hline \hline Mothers' occupation & 48 & 6.7 \\
Work & 135 & 29.5 \\
\hline House wife & & \\
\hline \hline Family income & 111 & \\
Enough & 18 & \\
Not enough & 54 & \\
Enough and more & & \\
\hline
\end{tabular}

Con. table (1)

\begin{tabular}{|l|c|c|}
\hline \multirow{2}{*}{ Socio-demographic } & \multicolumn{2}{|c|}{ Study Group } \\
\cline { 2 - 3 } Characteristics & No & 183 \\
\hline Numbers of living room & 29 & 15.8 \\
Less than 3 & 135 & 73.8 \\
3-5 & 19 & 10.4 \\
More than 5 & & \\
\hline Source of drink water & 112 & 61.1 \\
Public sources & 34 & 18.6 \\
Underground sources & \multicolumn{2}{|c|}{37} \\
Privet sources & \multicolumn{2}{|c|}{20.2} \\
\hline
\end{tabular}

Vol. 2 No. 2 May 2012 


\section{Tanta Scientific Nursing Journal}

Table (2): Distribution of the studied sample according to their reaction, physical symptoms at menarche and their sources of information about menstruation.

\begin{tabular}{|c|c|c|}
\hline \multirow[t]{2}{*}{ Student's knowledge } & \multicolumn{2}{|c|}{$\begin{array}{c}\text { Study Group } \\
183\end{array}$} \\
\hline & No & $\%$ \\
\hline \multicolumn{3}{|l|}{ Reaction of menarche } \\
\hline Crying & 10 & 5.5 \\
\hline Embarrassed & 11 & 6.0 \\
\hline Excited and joyful & 8 & 4.4 \\
\hline Run to mother & 129 & 70.5 \\
\hline Run to friend & 2 & 1.1 \\
\hline Run to sister & 16 & 8.7 \\
\hline Not tell anyone & 7 & 3.8 \\
\hline \multicolumn{3}{|l|}{ Physical symptoms of menarche } \\
\hline Abdominal & 123 & 67.2 \\
\hline back pain & 24 & 13.1 \\
\hline Sleeplessness & 17 & 9.3 \\
\hline Weakness & 14 & 7.7 \\
\hline Heavy bleeding & 5 & 2.7 \\
\hline Non of the above & 13 & 7.1 \\
\hline \multicolumn{3}{|l|}{ Menstruation is a special event. } \\
\hline Yes & 125 & 68.3 \\
\hline No & 58 & 31.7 \\
\hline \multicolumn{3}{|l|}{ Place of sleeping during menstruation } \\
\hline Same place & 162 & 88.5 \\
\hline Separated place & 21 & 11.5 \\
\hline \multicolumn{3}{|l|}{ Perform housing daily activity during menstruation } \\
\hline No & 156 & 85.2 \\
\hline $\begin{array}{l}\text { Awareness about menstruation before } \\
\text { encompassing menarche }\end{array}$ & Awareness about menstruation before & 47.0 \\
\hline Yes & 97 & 53.0 \\
\hline No & & \\
\hline
\end{tabular}

Vol. 2 No. 2 May 2012 


\section{Tanta Scientific Nursing Journal}

\begin{tabular}{|l||c||c|}
\hline \hline Previous information about menstruation & 126 & 68.9 \\
Yes & 57 & 31.1 \\
No & & \\
In case of yes, source & 112 & 61.2 \\
Mother & 11 & 6.0 \\
Friends & 3 & 1.6 \\
Teachers & 3 & 1.6 \\
Reading & 165 & \\
\hline \hline Preferred source of information about menstruation & 2 & 90.1 \\
Mother & 10 & 1.1 \\
Teachers & 6 & 5.5 \\
Doctors and school health nurse & 3.2 \\
Mass media & \multicolumn{2}{|c||}{} \\
\hline \hline
\end{tabular}

Table (3): Distribution of the studied sample according to their usage of pads during menstruation, advantages and disadvantages of pads.

\begin{tabular}{|l|c|c|}
\hline \multirow{2}{*}{ Practices regarding menstrual hygiene } & \multicolumn{2}{|c|}{ Study Group } \\
\cline { 2 - 3 } & No & \% \\
\hline Protective materials for menarche & & \\
Commercial pads & 152 & 83.1 \\
Old clothes & 4 & 2.2 \\
New clothes & 27 & 14.8 \\
\hline Prepare protective materials for menarche & & \\
By mother & 25 & 13.6 \\
By grand sister & 23 & 12.6 \\
Buy it & 135 & 73.7 \\
\hline Type of pads & & \\
Commercial pads & 148 & 80.9 \\
Old clothes & 11 & 6.0 \\
New clothes & 18 & 9.8 \\
All of the above & 6 & 3.3 \\
\hline
\end{tabular}

Vol. 2 No. 2 May 2012 


\section{Tanta Scientific Nursing Journal}

\begin{tabular}{|l|c|c|}
\hline Reuse of pads & 35 & 19.1 \\
Yes & 148 & 80.9 \\
No & 36 & \\
\hline Change pads at school & 147 & 80.7 \\
Yes & & \\
No & 6 & 3.3 \\
\hline Advantages of using sanitary pads & 53 & 29.0 \\
None & 95 & 51.9 \\
Comfortable & 13 & 7.1 \\
Good absorbent & 8 & 4.4 \\
Don't filtrate & 8 & 4.4 \\
Don't cause itching & & \\
Don't cause any discharge & 116 & 63.4 \\
\hline Disadvantages of pads & 44 & 24.0 \\
None & 23 & 12.6 \\
Expensive & & \\
Not comfortable & & \\
\hline Sources of information about practices $\quad$ regarding & & 61.2 \\
menstruation & & 14.2 \\
Mother and relatives & & 8.2 \\
Friends & & 14.3 \\
Teachers & & 26 \\
Doctors and school health nurse & & \\
Mass media & & \\
\hline
\end{tabular}




\section{Tanta Scientific Nursing Journal}

Table (4): Distribution of the studied sample according to their health problems during menstruation

\begin{tabular}{|l|c|c||}
\hline \multicolumn{1}{|c|}{ Health problems } & \multicolumn{2}{c|}{ Study Group } \\
\cline { 2 - 3 } & No & \% \\
\hline Health problem during menstruation & 152 & 83.1 \\
Yes & 31 & 16.9 \\
No & & \\
In case of yes & 37 & 20.2 \\
Irregularity & 11 & $6 . .0$ \\
Excess flow & 87 & 47.5 \\
Abdominal and back pain & 4 & 2.2 \\
Headache & 9 & $4 . .9$ \\
Mood change & 4 & $2 . .2$ \\
Sleeplessness & & \\
\hline \hline Severity of pain & 73 & 39.9 \\
Not interfere school activities & 89 & 48.6 \\
Interfere school activities & 21 & 11.5 \\
Accompanied with vomiting and nausea & & \\
\hline Intervention for relieving health problems & 48 & 26.2 \\
Go to family member & 31 & 16.9 \\
Go to doctor or school health nurse & 26 & 14.2 \\
Take medication without consultation & 11 & 6.0 \\
Go to hospital & 67 & 36.6 \\
Use traditional medicine & & \\
\hline Feeling with comfort in school during menstruation & 39 & 21.3 \\
Yes & 144 & 78.7 \\
No & 94 & 48.6 \\
\hline Effect of health problems on school achievement & 51.4 \\
Yes & & \\
No & & \\
\hline \hline
\end{tabular}

Vol. 2 No. 2 May 2012 
Tanta Scientific Nursing Journal

Table (5): Distribution of the studied sample according to their specific knowledge regarding menstruation .

\begin{tabular}{|c|c|c|c|c|c|c|c|c|}
\hline \multirow[t]{2}{*}{ Items } & \multicolumn{2}{|c|}{$\begin{array}{c}\text { Preprogra } \\
\text { m }\end{array}$} & \multicolumn{2}{|c|}{$\begin{array}{c}\text { Immediate } \\
\text { post } \\
\text { program } \\
\text { n=183 }\end{array}$} & \multicolumn{2}{|c|}{$\begin{array}{c}3 \text { months } \\
\text { post- } \\
\text { program } \\
\text { n=183 }\end{array}$} & \multirow[t]{2}{*}{$\mathbf{X}^{2}$} & \multirow[t]{2}{*}{$\mathbf{P}$} \\
\hline & $\mathbf{N}$ & $\%$ & $\mathbf{N}$ & $\%$ & $\mathbf{N}$ & $\%$ & & \\
\hline \multicolumn{9}{|l|}{$\begin{array}{l}\text { Age of menarche, in } \\
\text { general }\end{array}$} \\
\hline $9-11$ & 34 & 18.6 & 0 & 0.0 & 5 & 2.7 & & \\
\hline $9-16$ & 29 & 15.8 & 165 & 90.2 & 160 & 87.4 & $66.93 *$ & $0.0001 *$ \\
\hline $12-14$ & 79 & 43.2 & 18 & 9.8 & 18 & 9.8 & & \\
\hline $15-17$ & 12 & 6.6 & 0 & 0.0 & 0 & 0.0 & & \\
\hline Don't known & 29 & 15.8 & 0 & 0.0 & 0 & 0.0 & & \\
\hline \multicolumn{9}{|l|}{$\begin{array}{l}\text { Average of menstrual flow } \\
\text { in normal girls }\end{array}$} \\
\hline $3-5$ & 95 & 51.9 & 13 & 7.1 & 25 & 13.7 & & \\
\hline $3-7$ & 22 & 12.0 & 170 & 92.9 & 158 & 86.3 & 74.09* & $0.0002 *$ \\
\hline $5-7$ & 17 & 9.3 & 0 & 0.0 & 0 & 0.0 & & \\
\hline Don't known & 49 & 26.8 & 0 & 0.0 & 0 & 0.0 & & \\
\hline \multicolumn{9}{|l|}{$\begin{array}{l}\text { Average of menstrual } \\
\text { interval in normal girls }\end{array}$} \\
\hline $20-35$ & 52 & 28.4 & 177 & 96.7 & 178 & 97.3 & $66.83 *$ & $0.0001 *$ \\
\hline $26-30$ & 49 & 26.8 & 4 & $2 . .2$ & 5 & 2.7 & & \\
\hline $30-35$ & 27 & 14.8 & 2 & 1.1 & 0 & 0.0 & & \\
\hline Don't known & 55 & 30.0 & 0 & 0.0 & 0 & 0.0 & & \\
\hline \multicolumn{9}{|l|}{ Meaning of menstruation } \\
\hline Physiological process & 57 & 31.1 & 178 & 97.3 & 178 & 97.3 & & \\
\hline Pathological process & 27 & 14.8 & 0 & 0.0 & 5 & 2.7 & $54.87 *$ & $0.0001 *$ \\
\hline Curse from God & 34 & 18.6 & 5 & 2.7 & 0 & 0.0 & & \\
\hline Don't known & 65 & 35.5 & 0 & 0.0 & 0 & 0.0 & & \\
\hline
\end{tabular}

Vol. 2 No. 2 May 2012 


\section{Tanta Scientific Nursing Journal}

\begin{tabular}{|c|c|c|c|c|c|c|c|c|}
\hline Causes of menstruation & & & & & & & \multirow{7}{*}{ 24.96* } & \multirow{7}{*}{$0.0002 *$} \\
\hline Age & 35 & 19.1 & 0 & 0.0 & 1 & 0.5 & & \\
\hline Hormonal activity & 37 & 20.2 & 180 & 98.5 & 178 & 97.3 & & \\
\hline Curse from God & 3 & 1.6 & 1 & 0.5 & 1 & 0.5 & & \\
\hline Enzymes changes & 34 & 18.6 & 1 & 0.5 & 1 & 0.5 & & \\
\hline Age and hormonal activity & 22 & 12.0 & 1 & $0 . .5$ & 2 & 1.1 & & \\
\hline Don't know & 52 & 28.4 & 0 & 0.0 & 0 & 0.0 & & \\
\hline \multicolumn{8}{|l|}{ Origin of bleeding } & \multirow{6}{*}{$0.0001 *$} \\
\hline Bladder & 8 & 4.4 & 1 & 0.5 & 178 & 1.1 & \multirow{5}{*}{$34.87 *$} & \\
\hline Uterus & 57 & 31.1 & 180 & 98.5 & 178 & 97.3 & & \\
\hline Fallopian tube & 25 & 13.7 & 1 & 0.5 & 1 & 0.5 & & \\
\hline Vagina & 22 & 12.0 & 1 & 0.5 & 1 & 0.5 & & \\
\hline Don't know & 71 & 38.8 & 0 & 0.0 & 1 & 0.5 & & \\
\hline
\end{tabular}

Vol. 2 No. 2 May 2012 
Tanta Scientific Nursing Journal

Table (6): Distribution of the studied sample according to their specific knowledge regarding restricted practices during menstruation

\begin{tabular}{|c|c|c|c|c|c|c|c|c|}
\hline \multirow[t]{2}{*}{ Items } & \multicolumn{2}{|c|}{$\begin{array}{c}\underset{\text { Preprogra }}{\text { m }} \\
\mathbf{n}=\mathbf{1 8 3}\end{array}$} & \multicolumn{2}{|c|}{$\begin{array}{c}\text { Immediate } \\
\text { post } \\
\text { program } \\
\text { n=183 }\end{array}$} & \multicolumn{2}{|c|}{$\begin{array}{l}3 \text { months } \\
\text { post- } \\
\text { program } \\
\mathbf{n}=183\end{array}$} & \multirow[t]{2}{*}{$X^{2}$} & \multirow[t]{2}{*}{$\mathbf{P}$} \\
\hline & $\mathbf{N}$ & $\%$ & $\mathbf{N}$ & $\%$ & $\mathbf{N}$ & $\%$ & & \\
\hline $\begin{array}{l}\text { 1- Attendance to school } \\
\text { during menstruation } \\
\text { Yes } \\
\text { No }\end{array}$ & $\begin{array}{c}79 \\
104 \\
\end{array}$ & $\begin{array}{l}43.2 \\
56.8 \\
\end{array}$ & $\begin{array}{c}165 \\
18 \\
\end{array}$ & $\begin{array}{c}90.2 \\
9.8\end{array}$ & $\begin{array}{c}160 \\
23\end{array}$ & $\begin{array}{l}87.4 \\
12.6\end{array}$ & $\begin{array}{c}\mathbf{N} \\
50.87 *\end{array}$ & $0.0001^{*}$ \\
\hline $\begin{array}{llr}\begin{array}{l}\text { 2- Go to } \\
\text { occasion } \\
\text { menstruation }\end{array} & \begin{array}{r}\text { religious } \\
\text { during }\end{array} \\
\text { Yes } & \\
\text { No } & & \\
& \end{array}$ & $\begin{array}{c}130 \\
53\end{array}$ & $\begin{array}{l}71.0 \\
29.0\end{array}$ & $\begin{array}{c}180 \\
3\end{array}$ & $\begin{array}{c}98.5 \\
1.5\end{array}$ & $\begin{array}{c}178 \\
5\end{array}$ & $\begin{array}{c}97.3 \\
2.7\end{array}$ & $32.47^{*}$ & 0.0001* \\
\hline 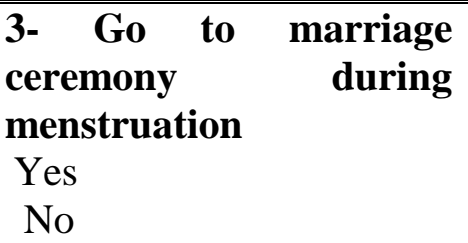 & $\begin{array}{c}75 \\
108\end{array}$ & $\begin{array}{l}41.0 \\
59.0\end{array}$ & $\begin{array}{c}180 \\
3\end{array}$ & $\begin{array}{c}98.5 \\
1.5\end{array}$ & $\begin{array}{c}175 \\
8\end{array}$ & $\begin{array}{c}95.6 \\
4.4\end{array}$ & $30.87 *$ & $.0001 *$ \\
\hline $\begin{array}{l}\text { 4- Eat all types of food } \\
\text { during menstruation } \\
\text { Yes } \\
\text { No }\end{array}$ & $\begin{array}{c}45 \\
138 \\
\end{array}$ & $\begin{array}{l}24.6 \\
75.4 \\
\end{array}$ & $\begin{array}{c}183 \\
0 \\
\end{array}$ & $\begin{array}{c}100.0 \\
0.0\end{array}$ & $\begin{array}{c}180 \\
3 \\
\end{array}$ & $\begin{array}{c}98.5 \\
1.5 \\
\end{array}$ & $25.27 *$ & 0.0001* \\
\hline $\begin{array}{l}\text { 5- Cook food during } \\
\text { menstruation } \\
\text { Yes } \\
\text { No }\end{array}$ & $\begin{array}{c}34 \\
149\end{array}$ & $\begin{array}{l}18.6 \\
81.4\end{array}$ & $\begin{array}{c}178 \\
5\end{array}$ & $\begin{array}{c}97.3 \\
2.7\end{array}$ & $\begin{array}{c}165 \\
18\end{array}$ & $\begin{array}{c}90.2 \\
9.8\end{array}$ & $42.57 *$ & $0.0001 *$ \\
\hline $\begin{array}{lr}\begin{array}{l}\text { 6-Perform } \\
\text { work }\end{array} & \begin{array}{r}\text { household } \\
\text { during }\end{array} \\
\text { menstruation } & \\
\text { Yes } & \\
\text { No } & \end{array}$ & $\begin{array}{c}27 \\
156\end{array}$ & $\begin{array}{l}14.8 \\
85.2\end{array}$ & $\begin{array}{c}178 \\
5\end{array}$ & $\begin{array}{c}97.3 \\
2.7\end{array}$ & $\begin{array}{c}160 \\
23\end{array}$ & $\begin{array}{l}87.4 \\
12.6\end{array}$ & $47.77 *$ & 0.0001* \\
\hline
\end{tabular}

Vol. 2 No. 2 May 2012 
Tanta Scientific Nursing Journal

Table (7): Distribution of the studied sample according to their specific practices regarding menstrual hygiene

\begin{tabular}{|c|c|c|c|c|c|c|c|c|}
\hline \multirow[t]{2}{*}{ Practices items } & \multicolumn{2}{|c|}{$\begin{array}{c}\text { Preprogra } \\
\text { m } \\
n=183\end{array}$} & \multicolumn{2}{|c|}{$\begin{array}{c}\text { Immediate } \\
\text { post } \\
\text { program } \\
\text { n=183 }\end{array}$} & \multicolumn{2}{|c|}{$\begin{array}{c}3 \text { months } \\
\text { post- } \\
\text { program } \\
n=183\end{array}$} & \multirow[t]{2}{*}{$\mathbf{X}^{2}$} & \multirow[t]{2}{*}{$\mathbf{P}$} \\
\hline & $\mathbf{N}$ & $\%$ & $\mathbf{N}$ & $\%$ & $\mathbf{N}$ & $\%$ & & \\
\hline $\begin{array}{l}\text { Bathing during } \\
\text { menstruation } \\
\text { Yes } \\
\text { No }\end{array}$ & $\begin{array}{l}84 \\
99\end{array}$ & $\begin{array}{l}45.9 \\
54.1\end{array}$ & $\begin{array}{c}180 \\
3\end{array}$ & $\begin{array}{c}98.5 \\
1.5\end{array}$ & $\begin{array}{c}175 \\
8\end{array}$ & $\begin{array}{c}95.6 \\
4.4\end{array}$ & $46.98 *$ & $0.0001 *$ \\
\hline $\begin{array}{l}\text { Time of bathing during } \\
\text { menstruation } \\
\text { At first day } \\
\text { At third day } \\
\text { Daily }\end{array}$ & $\begin{array}{c}7 \\
28 \\
49\end{array}$ & $\begin{array}{c}3.8 \\
15.3 \\
26.8\end{array}$ & $\begin{array}{c}5 \\
0 \\
178\end{array}$ & $\begin{array}{c}2.7 \\
0.0 \\
97.3\end{array}$ & $\begin{array}{c}0 \\
5 \\
178\end{array}$ & $\begin{array}{c}0.0 \\
2.7 \\
97.3\end{array}$ & $64.19 *$ & $0.0002 *$ \\
\hline $\begin{array}{l}\text { Usage of pads during } \\
\text { menstruation } \\
\text { Yes } \\
\text { No } \\
\text { In case of yes, type } \\
\text { Commercial pads } \\
\text { Old clothes } \\
\text { New clothes } \\
\text { All of the above }\end{array}$ & $\begin{array}{c}148 \\
11 \\
18 \\
6\end{array}$ & $\begin{array}{c}80.9 \\
6.0 \\
9.8 \\
3.3\end{array}$ & $\begin{array}{c}177 \\
6 \\
0 \\
0\end{array}$ & $\begin{array}{c}96.7 \\
3.3 \\
0.0 \\
0.0\end{array}$ & $\begin{array}{c}177 \\
6 \\
0 \\
0\end{array}$ & $\begin{array}{c}96.7 \\
3.3 \\
0.0 \\
0.0\end{array}$ & $56.83 *$ & $0.0001 *$ \\
\hline $\begin{array}{l}\text { Frequency of change of } \\
\text { pads /day } \\
\text { Once } \\
\text { Twice } \\
\text { Thrice } \\
\text { On need }\end{array}$ & $\begin{array}{l}36 \\
93 \\
43 \\
11\end{array}$ & $\begin{array}{c}19.7 \\
50.8 \\
23.5 \\
6.0\end{array}$ & $\begin{array}{c}1 \\
1 \\
1 \\
180\end{array}$ & $\begin{array}{c}0.5 \\
0.5 \\
0.5 \\
98.5\end{array}$ & $\begin{array}{c}2 \\
2 \\
2 \\
177\end{array}$ & $\begin{array}{c}1.1 \\
1.1 \\
1.1 \\
96.7\end{array}$ & $54.87 *$ & $0.0001 *$ \\
\hline $\begin{array}{l}\text { Pads disposal } \\
\text { In house dustbin } \\
\text { In the bath } \\
\text { Burial } \\
\text { Burn }\end{array}$ & $\begin{array}{c}84 \\
55 \\
40 \\
4 \\
\end{array}$ & $\begin{array}{c}45.9 \\
30.1 \\
21.9 \\
2.2\end{array}$ & $\begin{array}{c}180 \\
3 \\
0 \\
0\end{array}$ & $\begin{array}{c}98.5 \\
1.5 \\
0.0 \\
0.0\end{array}$ & $\begin{array}{c}178 \\
5 \\
0 \\
0\end{array}$ & $\begin{array}{c}97.3 \\
2.7 \\
0.0 \\
0.0\end{array}$ & $34.96 *$ & $0.0001 *$ \\
\hline
\end{tabular}

Vol. 2 No. 2 May 2012 
Tanta Scientific Nursing Journal

\begin{tabular}{|c|c|c|c|c|c|c|c|c|}
\hline 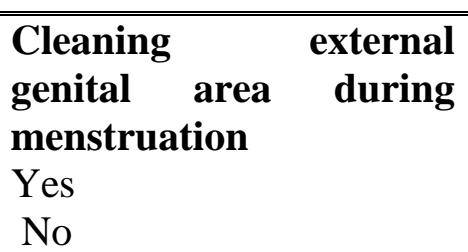 & $\begin{array}{c}167 \\
16\end{array}$ & $\begin{array}{c}91.3 \\
8.7\end{array}$ & $\begin{array}{c}183 \\
0\end{array}$ & $\begin{array}{c}100.0 \\
0.0\end{array}$ & $\begin{array}{c}183 \\
0\end{array}$ & $\begin{array}{c}100.0 \\
0.0\end{array}$ & $16.25 *$ & $0.0001^{*}$ \\
\hline $\begin{array}{l}\text { Cleaning materials } \\
\text { Soap and water } \\
\text { Plain water only } \\
\text { Water and antiseptic } \\
\text { solution }\end{array}$ & $\begin{array}{l}106 \\
37 \\
40\end{array}$ & $\begin{array}{l}57.9 \\
20.2 \\
21.9\end{array}$ & $\begin{array}{c}106 \\
37 \\
40\end{array}$ & $\begin{array}{l}57.9 \\
20.2 \\
21.9\end{array}$ & $\begin{array}{c}106 \\
37 \\
40\end{array}$ & $\begin{array}{l}57.9 \\
20.2 \\
21.9\end{array}$ & 2.02 & 0.214 \\
\hline $\begin{array}{l}\text { Keeping privacy during } \\
\text { doing hygiene } \\
\text { Yes } \\
\text { No }\end{array}$ & $\begin{array}{c}162 \\
21 \\
\end{array}$ & $\begin{array}{l}88.5 \\
11.5\end{array}$ & $\begin{array}{c}180 \\
3\end{array}$ & $\begin{array}{c}98.5 \\
1.5\end{array}$ & $\begin{array}{c}178 \\
5\end{array}$ & $\begin{array}{c}97.3 \\
2.7 \\
\end{array}$ & $26.25 *$ & $0.0001 *$ \\
\hline $\begin{array}{l}\text { Daily living activity } \\
\text { during } \\
\text { menstruation(cleansing } \\
\text {,grooming, cooking) } \\
\text { Yes } \\
\text { No }\end{array}$ & $\begin{array}{c}53 \\
130\end{array}$ & $\begin{array}{l}29.0 \\
71.0\end{array}$ & $\begin{array}{c}180 \\
3\end{array}$ & $\begin{array}{c}98.5 \\
1.5\end{array}$ & $\begin{array}{c}178 \\
5\end{array}$ & $\begin{array}{c}97.3 \\
2.7\end{array}$ & 36.28* & $0.0001 *$ \\
\hline $\begin{array}{ll}\text { Rest } & \text { during } \\
\text { menstruation } & \\
\text { Yes } & \\
\text { No } & \end{array}$ & $\begin{array}{c}125 \\
58\end{array}$ & $\begin{array}{l}68.3 \\
31.7\end{array}$ & $\begin{array}{c}183 \\
0\end{array}$ & $\begin{array}{c}100.0 \\
0.0\end{array}$ & $\begin{array}{c}183 \\
0\end{array}$ & $\begin{array}{c}100.0 \\
0.0\end{array}$ & $10.25 *$ & $0.0001 *$ \\
\hline
\end{tabular}

Table (8): Distribution of the studied sample according to presence of facilities for hygienic care during menstruation at home

\begin{tabular}{|c|c|c|}
\hline \multirow{2}{*}{$\begin{array}{l}\text { Facilities for hygienic care during menstruation at } \\
\text { home }\end{array}$} & \multicolumn{2}{|c|}{$\begin{array}{c}\text { Study Group } \\
183\end{array}$} \\
\hline & No & $\%$ \\
\hline \multicolumn{3}{|l|}{ Special room } \\
\hline Yes & 105 & 57.4 \\
\hline No & 78 & 42.6 \\
\hline \multicolumn{3}{|l|}{ Water and waste disposal } \\
\hline Yes & 161 & 88.0 \\
\hline No & 22 & 12.0 \\
\hline
\end{tabular}

Vol. 2 No. 2 May 2012 
Tanta Scientific Nursing Journal

\begin{tabular}{|l|c|c|}
\hline Number of bathroom & 126 & 68.9 \\
One & 57 & 31.1 \\
Two & 154 & 84.2 \\
\hline Enough money for buying pads & 29 & 15.8 \\
Yes & 175 & 95.8 \\
No & 8 & 4.4 \\
\hline Having enough cleansing materials (soap ,antiseptic & & \\
solution and shampoo) & & \\
Yes & & \\
No &
\end{tabular}

Table (9): Distribution of the schools according to presence of facilities for hygienic care .

\begin{tabular}{|l||c|c|}
\hline \multicolumn{1}{|c||}{ Facilities } & \multicolumn{2}{c|}{ School } \\
& No & \% \\
\cline { 2 - 3 } & & \\
\hline Type of school & 5 & 100.0 \\
Government & & \\
\hline Number of students & 1 & 20.0 \\
Less than 250 & 1 & 20.0 \\
250-350 & 3 & 60.0 \\
More than 350 & 5 & \\
\hline Number of toilets & & \\
More than 5 & 2 & 400.0 \\
\hline Number of water closets & 2 & 20.0 \\
Less than 5 & & \\
5 & 2 & 40.0 \\
More than 5 & 1 & 20.0 \\
\hline Number of bins at latrines & 2 & 40.0 \\
Less than 5 & & \\
5 & & \\
More than 5 & & \\
&
\end{tabular}

Vol. 2 No. 2 May 2012 


\section{Tanta Scientific Nursing Journal}

\begin{tabular}{|c|c|c|}
\hline $\begin{array}{l}\text { Number of latrines designated for girls } \\
\text { More than } 5\end{array}$ & 5 & 100.0 \\
\hline $\begin{array}{l}\text { Number of tap water } \\
\text { More than } 5\end{array}$ & 5 & 100.0 \\
\hline $\begin{array}{l}\text { Available of tap water near and in the latrines } \\
\text { Yes }\end{array}$ & 5 & 100.0 \\
\hline $\begin{array}{l}\text { Availability of water } \\
\text { Yes } \\
\text { No }\end{array}$ & $\begin{array}{l}4 \\
1\end{array}$ & $\begin{array}{l}80.0 \\
20.0\end{array}$ \\
\hline $\begin{array}{l}\text { Availability of bins } \\
\text { Yes }\end{array}$ & 5 & 100.0 \\
\hline $\begin{array}{l}\text { Availability of pit for waste disposal } \\
\text { Yes } \\
\text { No }\end{array}$ & $\begin{array}{l}2 \\
3\end{array}$ & $\begin{array}{l}40.0 \\
60.0\end{array}$ \\
\hline $\begin{array}{l}\text { Availability of place at school for burning waste disposal } \\
\text { Yes } \\
\text { No }\end{array}$ & $\begin{array}{l}3 \\
2\end{array}$ & $\begin{array}{l}60.0 \\
40.0\end{array}$ \\
\hline $\begin{array}{l}\text { Availability of cleanliness of latrines } \\
\text { Yes }\end{array}$ & 5 & 100.0 \\
\hline $\begin{array}{l}\text { Numbers of workers assigned to clean the latrines } \\
\text { Less than } 3\end{array}$ & 5 & 100.0 \\
\hline $\begin{array}{l}\text { The daily schedule for cleanliness latrines } \\
\text { Once /day } \\
\text { Twice/day }\end{array}$ & $\begin{array}{l}1 \\
4\end{array}$ & $\begin{array}{l}20.0 \\
80.0\end{array}$ \\
\hline $\begin{array}{l}\text { Clinic in the school } \\
\text { Yes }\end{array}$ & 5 & 100.0 \\
\hline $\begin{array}{l}\text { Social workers the school } \\
\text { Yes }\end{array}$ & 5 & 100.0 \\
\hline
\end{tabular}

Vol. 2 No. 2 May 2012 
Table (10): Score of knowledge among studied sample regarding menstrual hygiene Pre, Immediate and 3 Months Post-Program.

\begin{tabular}{|c|c|c|c|c|c|c|}
\hline \multirow[t]{3}{*}{ Time of assessment } & \multicolumn{6}{|c|}{$\begin{array}{l}\text { score of knowledge among studied sample } \\
\text { regarding menstrual hygiene } \\
n=183\end{array}$} \\
\hline & \multicolumn{2}{|c|}{ Poor } & \multicolumn{2}{|c|}{ Moderate } & \multicolumn{2}{|c|}{ Good } \\
\hline & $\overline{\mathbf{N}}$ & $\%$ & $\overline{\mathbf{N}}$ & $\%$ & $\mathbf{N}$ & $\%$ \\
\hline Pre-program & 90 & 49.2 & 76 & 41.5 & 17 & 9.3 \\
\hline Immediately post-program & 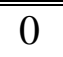 & 0.0 & 20 & 10.9 & 163 & 89.1 \\
\hline Three months post-program & 2 & 1.1 & 25 & 13.7 & 156 & 85.2 \\
\hline $\mathbf{F}$ & \multicolumn{6}{|c|}{$194.26 *$} \\
\hline $\mathbf{P}$ & \multicolumn{6}{|c|}{$0.0001 *$} \\
\hline
\end{tabular}

Table (11): Score of practices among studied sample regarding menstrual hygiene Pre, Immediate and 3 Months Post-Program.

\begin{tabular}{|c|c|c|c|c|c|c|}
\hline \multirow[t]{3}{*}{ Time of assessment } & \multicolumn{6}{|c|}{$\begin{array}{l}\text { Score of practices among studied sample } \\
\text { regarding menstrual hygiene } \\
n=183\end{array}$} \\
\hline & \multicolumn{2}{|c|}{ Poor } & \multicolumn{2}{|c|}{ Moderate } & \multicolumn{2}{|c|}{$\overline{\text { Good }}$} \\
\hline & $\mathbf{N}$ & $\%$ & $\mathbf{N}$ & $\%$ & $\mathbf{N}$ & $\%$ \\
\hline Pre-program & 70 & 38.2 & 100 & 54.7 & 13 & 7.1 \\
\hline Immediately post-program & 2 & 1.1 & 25 & 13.7 & 156 & 85.2 \\
\hline Three months post-program & 2 & 1.1 & 35 & 19.1 & 146 & 79.8 \\
\hline $\mathbf{F}$ & \multicolumn{6}{|c|}{$162.14 *$} \\
\hline 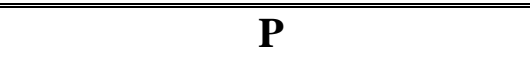 & \multicolumn{6}{|c|}{$0.0001 *$} \\
\hline
\end{tabular}


Table (12) Relationship between knowledge and practices of the studied students regarding menstrual hygiene pre, post and 3 months post-program.

\begin{tabular}{|c|c|c|c|c|c|c|}
\hline \multirow[t]{2}{*}{ Items } & \multicolumn{2}{|c|}{$\begin{array}{c}\text { Pre } \\
(n=183)\end{array}$} & \multicolumn{2}{|c|}{$\begin{array}{c}\text { Post } \\
(n=183)\end{array}$} & \multicolumn{2}{|c|}{$\begin{array}{c}3 \text { months post- } \\
\text { program } \\
(n=183)\end{array}$} \\
\hline & $\mathbf{X}^{2}$ & 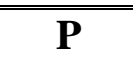 & $\mathbf{X}^{2}$ & 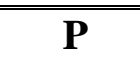 & $\mathrm{X}^{2}$ & $\overline{P \mathbf{P}}$ \\
\hline Knowledge & 32.2 & $0.000^{*}$ & 94.5 & $0.001^{*}$ & 90.3 & $0.001 *$ \\
\hline Practices & 22.2 & $0.001^{*}$ & 97.5 & $0.001^{*}$ & 81 & $0.001 *$ \\
\hline
\end{tabular}

Figure (1): Relationship between knowledge and practices of the studied students regarding menstrual hygiene pre, post and 3 months post-program.
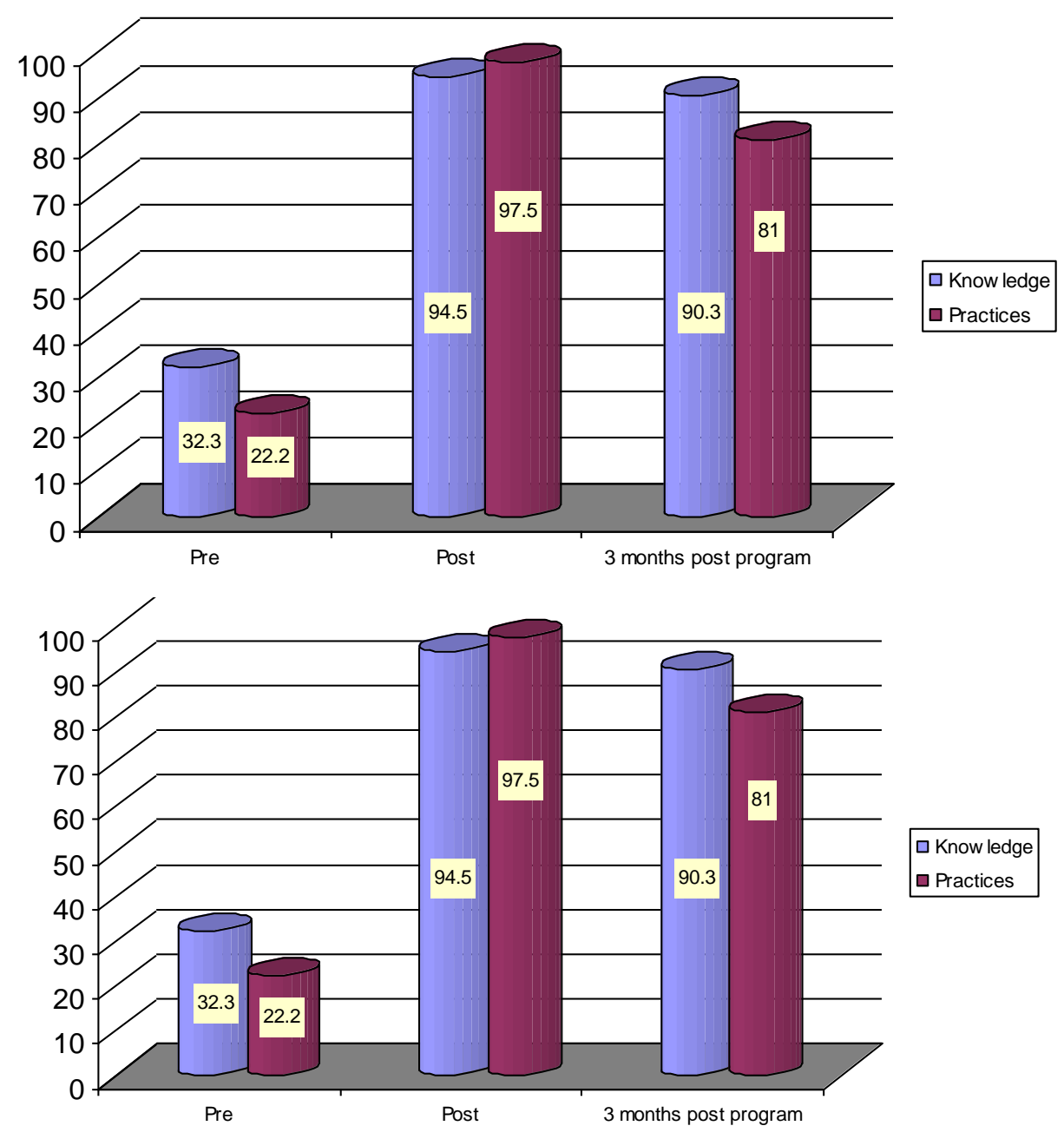

Vol. 2 No. 2 May 2012 


\section{References}

1. Abera Y. Menarche, Menstruation related Problems and Practices among Adolescent High School Girls in Addis Ababa. 2003/04.

2. Dhingra R, Kumar A and Kour. Knowledge and Practices Related to Menstruation among Tribal (Gujjar) Adolescent Girls. Ethno-Med, 2009; 3(1): 43-48.

3. Gangulis K. Adolescent Health. Indian Journal of Public Health, 2003; 47 (3): 5-15.

4. INCLEN International Clinic Epidemiology Network. 1998-2001. [last accessed on 2003 Jun 2]. Available from: http:// www. inclen.org.

5. Rao R, Lena A, Nairi N, Kamath V, Kamath A. Effectiveness of Reproductive Health Education Among Rural Adolescent Girls A School Based Intervention Study In Udupi Taluk, Karnataka. Indian Journal of Medical Science, 2008; 62(11):439-443.

6. http://www.unicef.org/egypt/children_15 1.html. Adolescence .25/ o6/ 2011.

7. .http://www.unicef.org/infobycountry/eg ypt_statistic.html.Adolescents $.24 / 06 / 2011$.

8. Chumlea W, Schubert C, Roche A, Kulin H, Lee P, Himes J and Sun S. Age at menarche and racial comparisons in US girls. Pediatrics, 2003; 111(1):11013.
9. Thomas F, Renaud F, Benefice E, de Meeüs $\mathrm{T}$ and Guegan J. International variability of ages at menarche and menopause: patterns and main determinants. Human Biology, 2001; 73(2):271-90.

10. Kaplowitz P. Pubertal development in girls: secular trends. Current Opinion in Obstetrics \& Gynecology, 2006; 18(5):487-91.

11. Abioye-Kuteyi E, Ojofeitimi E, Aina O, Kio F, Aluko $\mathrm{Y}$ and Mosuro O. The influence of socioeconomic and nutritional status on menarche in Nigerian school girls. Nutrition and Health,1997;11(3):185-95.

12. Adams Hillard P. Menstruation in young girls: a clinical perspective. Obstetrics and Gynecology, 2002; 99(4):655-62.

13. Diaz A, Laufer $M$ and Breech L. Menstruation in girls and adolescents: using the menstrual cycle as a vital sign. Pediatrics, 2006; 118(5):2245-50.

14. Simes $M$ and Berg D. Surreptitious Learning : Menarche and Menstrual Product Advertisements. Health Care Women , 2001;22(5): 455- 69.

15. Abd-Ella N. Premenarcheal health education needs among early adolescent girls. Thesis, M.Sc., Faculty of nursing, Alexandria University.2010.

16. Adhikari P, Kadel B , Dhungel S and Mandal A. Knowledge and Practices regarding Menstrual Hygiene among 
Rural Adolescent Girls of Nepal; Kathmandu University Medical Journal, 2007; 5 (3): 382-86.

17. Dasgupta A and Sarkar M. Menstrual Hygiene: How Hygienic is the Adolescent Girl? Indian Journal of Community Medicine, 2008; 33 (2): 7780 .

18. Nemade D, AnjenayaS and Gujar R. Impact of Health Education on Knowledge and Practices about Menstruation among Adolescent School Girls of Kalamboli, Navi-Mumbai. Health and Population: Perspectives and Issues, 2009; 32 (4), 167-75.

19. Adinma E. \& Adinma J. Perception and Practices on Menstruation amongst Nigerian Secondary School Girls. African Journal of Reproductive Health, 2008; 12 (1): 74-83.

20. Fetohy A. Impact of a Health Education Program for Secondary School Saudi Girls About Menstruation at Riyadh City. Journal of Egyptian Public Health Association, 2007; 82 (1 \& 2): 105-26.

21. Abraham S, Fraser I, Gebski V, Knight C, Liewellyn-Jones D, Mira M et al., Menstruation, menstrual protection and menstrual cycle problems: The knowledge, attitudes and practices of young Australian women. Med J aust, 1985;142(4): 247-51.

22. Hassanen R, Tosson M and Abd ElElkareem H. Effect of health education and training program for secondary school students on menstruation at Assiut Governorate. Bulletin of High Institute of Public Health, 2004; 34(3): 575-94.

23. Mobarak E, Mohey A and Kishk N. Experience of menarche among girls in Alexandria: Community-based study, Alexandria 2003. Bulletin of High Institute of Public Health, 2004; 34(2):335-56.

24. Khanna A, Goyal Rand Bhawsar R. Menstrual practices and reproductive problems: a study of adolescent girls in Rajasthan. Journal of Health Management . 2005;7:91-107.

25. Chang Y and Chen Y. Menstrual Health Care Behavior and Associated Factors Among Female Elementary Students in the Hualien Region. Journal of Nursing Research, 2008, 16(1):8-15.

26. El-Gilany A, Badawi K and El-Fedawy S. Menstrual Hygiene among Adolescent Schoolgirls in Mansoura, Egypt. Reproductive Health Matters, 2005; 13(26):147-52.

27. Moawed S. Indigenous practices of Saudi girls in Riyadh during their menstrual period. Eastern Mediterranean Health Journal, 2001;7(1/2):197-203.

28. Ali T and Rizvi S. Menstrual knowledge and practices of female adolescents in urban Karachi, Pakistan. Journal of Adolescence xxx, $2009 ; 1-11$.

29. http://www.wateraid.org/documents/plug in_documents/wa_nep_mhm_rep_march 


\section{Tanta Scientific Nursing Journal}

2009.pdf. Is menstrual hygiene and

management an issue for adolescent school girls?,2009.

30. Narayan K, Srinivasa D , Pelto, P J and Veeramal $S$.Puberty rituals, reproductive knowledge and health of adolescent schoolgirls in South. Asia Pacific Population Journal ,2001;16(2) 225-38.

31. Omidvar $\mathrm{S}$ and BegumK. Factors influencing hygienic practices during menses among girls from south India- A cross sectional study. International Journal of Collaborative Research on Internal Medicine \& Public Health,2010;2(12) :411-23

32. ZegeyeD, Megabiaw B and Mulu A. Age at menarche and the menstrual pattern of secondary school adolescents in northwest Ethiopia. BMC Women's Health ,2009; 9(29)

33. Drakshayani D. Venkata R. A study on menstrual hygiene among rural adolescent girls.Indian journal of medical sciences, 1994. 48(6): 139. 